\title{
Effect of Cerium on Erythrocyte Mechanical Properties
}

\author{
Mehmet Uyuklu \\ Department of Physiology, School of Medicine, Bezmialem Vakif University, \\ Istanbul, Turkey \\ E-mail: muyuklu@bezmialem.edu.tr \\ ORCID: https://orcid.org/0000-0002-7100-9817
}

Accepted that submission is not being considered elsewhere. There is no conflict of interests.

\begin{abstract}
Lanthanide's are known as rare earth elements and are used in many areas. Although the place of Cerium in the Lanthanide family in its biological importance in mammalian physiology is not fully known, a human weighing $70 \mathrm{~kg}$ contains about $40 \mathrm{mg}$ Cerium. Soluble $\mathrm{Ce}^{3+}$ salts (nitrate, acetate, chloride, etc.) are used for many biomedical purposes and in particular act as calcium analogues in biological systems. In nonphysiological flow conditions occurring in extracorporeal circulation areas, increased calcium ions within the cell play a role in reducing erythrocyte deformability. In this study, it is aimed to show the possible effects of Cerium on changes in erythrocyte deformability in shear stress at sub-hemolytic level. For this purpose, blood samples were taken from adult male volunteers. Normal erythrocyte deformability was measured at nine shear rates between 0.5 and $50 \mathrm{~Pa}$, followed by stress application at a slip rate of $290 \mathrm{~Pa}$ for 300 seconds without removing the sample from the system, followed by erythrocyte deformability at shear rates of 0.5-50 Pa. There was no significant difference between the erythrocyte deformability values of the control and Cerium incubated blood samples before stress application. However, significant differences were found after stress application ( $p<0.01$ ). Incubation of erythrocytes with Cerium did not cause any change in erythrocyte deformability, but caused further deterioration of erythrocytes after mechanical stress. Cerium chloride, which we use in our study, should be kept in mind that under normal conditions, even if there is no negative effect on erythrocyte mechanics, conditions change, erythrocytes are exposed to short-term sub-hemolytic mechanical effects and their mechanical properties are deteriorated.
\end{abstract}

Keywords: Lanthanide, Cerium, Erythrocyte, Deformability, Mechanical Stress

DOI: $10.7176 / \mathrm{JSTR} / 5-8-11$

\section{Seryum’un Eritrosit Mekanik Özelliklerine Etkisi}

Özet:

Lanthanitler nadir toprak elementleri olarak bilinirler ve birçok alanda kullanılırlar. Lanthanit ailesinden olan Seryumun memeli fizyolojisindeki biyolojik önemindeki yeri tam olarak bilinmese de, $70 \mathrm{~kg}$ ağırlığındaki bir insanda yaklaşık $40 \mathrm{mg}$ Seryum bulunmaktadır. Çözülebilir $\mathrm{Ce}^{3+}$ tuzları (nitrat, asetat, klorür vb.) birçok biyomedikal amaçlar için kullanılmakta ve özellikle de biyolojik sistemlerde kalsiyum analogları olarak işlev görmektedir. Vücut dışı dolaşım alanlarında meydana gelen fizyolojik olmayan akım koşullarında hücre içinde artan kalsiyum iyonları, eritrosit deformabilitesinin azalmasında rol oynar. Bu çalışmada, sub-hemolitik düzeydeki kayma geriliminde eritrosit deformabilitesinde meydana gelen değişikliklere Seryum'un olası etkilerinin gösterilmesi amaçlanmıştır. $\mathrm{Bu}$ amaçla, yetişkin erkek gönüllülerden alınan kan örneklerinde sırasıyla; 0.5-50 Pa arasındaki dokuz kayma hızlarında normal eritrosit deformabilitesi ölçümü, bu ölçümün arkasından sistemdeki numuneyi çıkarmadan 300 saniye 290 $\mathrm{Pa}$ kayma hızında stres uygulaması, hemen arkasından ise tekrar 0.5-50 Pa kayma hızlarında eritrosit deformabilitesi ölçümü gerçekleştirilmiştir. Stres uygulamasından önceki Kontrol ve Seryum ile inkübe edilmiş kan örnekleriyle yapılan ölçümlerde, her iki örneğin de eritrosit deformabilite değerleri arasında anlamlı fark olmadığı bulunmuştur. Ancak, stres uygulamasından sonra önemli oranda farklar bulunmuştur $(\mathrm{p}<0.01)$. Eritrositlerin Seryum ile inkübasyonu, eritrosit deformabilitesinde herhangi bir değişime neden olmazken, mekanik stres sonrası eritrositlerin deformabilitesinin daha da bozulmasına neden olmuştur.

96 | $\mathrm{P}$ a g e

www.iiste.org 
Çalışmamızda da kullandığımız Seryum klorür'ün, normal şartlar altında eritrosit mekaniğine olumsuz bir etkisi olmasa da, şartların değiştiği, eritrositlerin kısa süreli sub-hemolitik mekanik etkilere maruz kaldığ durumlarda mekanik özelliklerinin bozulduğu göz önünde tutulmalıdır.

Anahtar Kelimeler: Lanthanit, Seryum, Eritrosit, Deformabilite, Mekanik Stres

\section{Giriş}

Lanthanitler, atom numaralar1 57 (Lanthanum) ile 71 (Lutetium) arasında olan "nadir toprak" elementleri olarak bilinirler. Kendilerine özgü yapılarından dolayı spesifik kimyasal, optik ve manyetik özelliklere sahiptirler. Günümüzde özellikle aydınlatma cihazları, lens, lazer, biyomedikal cihaz ve görüntüleme teknikleri, fiber optik ve sabit disk sürücüleri gibi birçok yerde kullanılmaktadır. Bunların dışında Lanthanitler'in eritrositlerin transmembran iyon transportunu, membran yapı ve fiziksel özelliklerini modüle edebileceğine ilişkin çalışmalar da bulunmaktadır (Sneddon 1987; Cheng ve diğ. 1999a; Cheng ve diğ. 1999b; Cheng ve diğ. 1999c). Yapılan çalışmalarda genellikle Lanthanitler'in hücreye füzyonuna, iyon transportuna, por oluşumuna, protein aggregasyonuna etkileri (Sun ve diğ. 1995; Herscher ve Rega 1996; Cheng ve diğ. 1999a; Cheng ve diğ. 1999b), Lanthanitler'in ve bunların iyonik yarıçapının eritrosit mekaniğine etkileri gösterilmiştir (Alexy ve diğ. 2011).

Seryum'un memeli fizyolojisindeki biyolojik önemindeki yeri tam olarak bilinmese de, çözülebilir $\mathrm{Ce}^{3+}$ tuzları (nitrat, asetat, klorür vb.) insanlar tarafindan geleneksel olarak anti-emetik, bakteriyostatik, bakteri yok edici, immünomodülatör ve anti-tümör aktiviteleri nedeniyle biyomedikal amaçlar için kullanılmıştır (Ji ve diğ. 2000; Jakupec ve diğ. 2005). Lanthanitler'in elektron kabuklarının özelliklerinden dolayı, fiziksel ve kimyasal özellikleri birbirlerine çok benzemektedir. Bu elementlerin biyolojik sistemlerde kalsiyum analogları olarak işlev gördüğ̈̈, enzimlerdeki (Martin and Richardson 1979) ve hücre zarı dâhil birçok proteinde kalsiyumun yerini alabildiği söylenmektedir (Dosremedios 1981).

Kırmızı kan hücreleri, normal yaşamlarının sonuna kadar dolaşım sisteminin farklı kademelerinde mekanik strese maruz kalırlar. Bunun sonucu olarak şekillerini değiştirerek, akım koşullarına oryente olurlar. Normal fizyolojik şartlarda oluşan bu stres, eritrositlerde hasara neden olmaz. Ancak, fizyolojik olmayan yapay organ ve cihazlardaki dolaşım koşullarında (kardiyopulmoner bypass, hemodiyaliz ekipmanları vs.) eritrositlerin şekillerinde değişiklik, membranlarında kopmalar ve bunun sonucunda da hemoliz meydana gelir (Dao ve diğ. 1994; Kuypers 1998; Baskurt ve diğ. 2004; Sakota ve diğ. 2008). Eritrositlerde hasar mekanizmalarının aktivasyonuna yol açan travma çeşitleri, sub-hemolitik ve hemolitik travma olmak üzere iki farklı grupta incelenir. Bunlar arasındaki en önemli fark, meydana getirdikleri hasarın derecesidir. Subhemolitik travma hemolize neden olmazken; hemolitik travma değişen oranlarda hemolize neden olmaktadır. Sub-hemolitik kayma gerilimi, eritrosit membranından iki yönlü ve konsantrasyon-bağımlı bir şekilde iyon geçişini indüklemektedir (Dao ve diğ. 1994). Bu iyon geçişleri, hücreden potasyum çıkısı ile hücreye kalsiyum ve sodyum girişini içermektedir. Mekanik stres ile aktive olan katyon kanallarından hücreye giren kalsiyum, hücre içinde düzenleyici mekanizmalarda görev alan çeşitli proteinleri aktive etmektedir. Bu çalışmada, sub-hemolitik düzeydeki kayma geriliminde eritrosit deformabilitesinde meydana gelen değişikliklere Seryum'un olası etkilerinin gösterilmesi amaçlanmıştır.

\section{Materyal ve Metot}

\subsection{Kan örnekleri}

Çalışma, 24-45 yaş arası 10 gönüllü erkek bireyden alınan kan örnekleri kullanılarak yapıldı. Deneklerin ön kol venlerinden Etilendiamintetraasetik'li (EDTA; $1.5 \mathrm{mg} / \mathrm{dl}$ ) tüplere alınan kan örnekleri, dakikada 1400 g'de beş dakika boyunca santrifüj edilip, plazmaları ayrıldı. Alınan kan örnekleri santrifüj edildikten sonra, eritrosit paketi Tris- $\mathrm{NaCl}(5 \mathrm{mM}$ Tris, $290 \mathrm{mOsm} / \mathrm{kg}, \mathrm{pH}=7.4)$ ile üç kez yıkandı. Örnekler kan alımını takiben hemen değerlendirildi ve her örnek üzerindeki çalışmalar, kan alımını izleyen dört saat içinde tamamlandi.

\subsection{Seryum 'un hazırlanmast}

Seryum (Klorür tuzu, Sigma Chemical Co., St. Louis, MO) final konsantrasyonu $50 \mu \mathrm{M}$ olacak şekilde Tris$\mathrm{NaCl}$ tamponunda hazırland. Tris- $\mathrm{NaCl}$ tamponunda, viskozitesi yaklaşı $100 \mathrm{cP}$ (centipoise) olacak şekilde polyvinylpyrrolidone $360(\mathrm{PVP}, 360 \mathrm{kDa})$ solüsyonu hazırlandı. Hazırlanan polimer solüsyonun viskozitesi $37^{\circ} \mathrm{C}$ 'de cone-plate viskozimetresinde (1/2RVDT, Brookfield Engineering Labs, Middleboro, MA) ölçüldü. Hazırlanan bu solüsyonun 2 ml'sine, $5 \mu$ l yıkanmış eritrosit paketi ve $20 \mu \mathrm{l}$ Seryum eklenip homojen olacak şekilde karıştırıldıktan sonra, yaklaşık 10 dakika oda isısında inkübasyona bırakıldı. İnkübasyondan sonra $37^{\circ} \mathrm{C}$ 'de deformabilite ölçümleri yapıldı. 


\subsection{Eritrosit deformabilitesinin ölçümü}

Eritrosit deformabilitesi, bir ektasitometre (LORRCA, RR Mechatronics, Hoorn, The Netherlands) kullanılarak, çeşitli sıvı kayma kuvvetlerinde lazer difraksiyon analizi ile değerlendirildi (Hardeman ve diğ. 1994). Önceden hazırlanan süspansiyonun yaklaşı bir mililitresi, aralarında $0.3 \mathrm{~mm}$ boşluk kalacak şekilde birbirine uyan iki cam silindirden oluşan bir viskozimetre sistemine yerleştirildi. İki cam silindirin arasındaki boşluğa doldurulan süspansiyon, dıştaki cam silindirin sistemi kontrol eden bilgisayar tarafından, uygun kayma kuvvetlerini oluşturmak üzere hesaplanan bir hızda döndürülmesiyle, bu kuvvetlerin etkisi altında bırakıldı. Belirlenen aralıktaki kayma kuvvetlerini oluşturacak dönme hızları, bilgisayar tarafından PVP çözeltisinin viskozitesi de dikkate alınarak hesaplandı. Bu sırada sabit silindirin içinde yer alan bir lazer kaynağından çıkan ışın, eritrosit süspansiyonuna ulaşmakta ve sonra bir ekran üzerine yansıyan difraksiyon paterni, süspansiyondaki eritrositlerin şeklini ve dönme hareketinin yarattığ akıma orientasyonlarını yansitmaktadır. Artan kayma kuvvetlerine paralel olarak, dairesel bir formdan elipsoid forma dönüşümün derecesi ile eritrositlerin şekil değiştirme yetenekleri (deformabilitesi) arasında doğru orantı vardır. Elipsoid difraksiyon paterninin uzun (A) ve kısa eksenlerinin (B) uzunluklarının bilgisayar tarafindan saptanmasıyla $\mathrm{EI}=(\mathrm{A}-\mathrm{B}) /(\mathrm{A}+\mathrm{B})$ şeklinde bir elongasyon indeksi (EI) hesaplanmaktadır. Ölçümler $37^{\circ} \mathrm{C}$ 'de yapıldı. EI değerleri dokuz kayma stresi arasında (0.5-50 Pa) ölçüldü. Bu değerler kullanılarak, her örnek için maksimum elongasyon indeksinin yarısı kadar şekil değiştirmeye neden olan kayma kuvveti $\left(\mathrm{SS}_{1 / 2}\right)$ Lineweaver-Burke analizi uygulanarak hesaplandı (Baskurt ve Meiselman 2004). $\mathrm{SS}_{1 / 2}$ değerindeki artış, deformabilitenin azalması olarak değerlendirilir.

\subsection{Sub-hemolitik stres uygulamast}

Sub-hemolitik stres uygulaması sırasıyla; 0.5-50 Pa arasındaki dokuz kayma hızlarında normal eritrosit deformabilitesi ölçümü, bu ölçümün arkasından sistemdeki numuneyi çıkarmadan 300 saniye 290 Pa kayma hızında stres uygulaması, hemen arkasından ise tekrar 0.5-50 Pa kayma hızlarında eritrosit deformabilitesi ölçümü şeklinde yapıldı. Verilerin analizi yapılırken, yüksek kayma hızından önce ve sonra olacak şekilde $\mathrm{SS}_{1 / 2}$ değerleri hesaplandi.

\subsection{Hesaplama ve istatistik}

Sonuçlar ortalama \pm standart hata olarak verildi. Gruplar arasındaki istatistiksel karşılaştırmalar "MannWhitney" testi ile değerlendirildi. 0.05 den küçük p değerleri istatistiksel olarak anlamlı kabul edildi (PRISM 6.0, GraphPad Software, Inc., La Jolla, CA, USA).

\section{Araştırma Bulguları ve Tartışma}

Eritrosit deformabilitesi, eritrositin kan akımı sırasında kendine uygulanan kuvvetlere yanıt olarak şekil değiştirmesi şeklinde tanımlanabilir (Mohandas ve diğ. 1980; Mohandas ve diğ. 1983; Mohandas 1992; Nash ve Gratzer 1993). Eritrositlerin kendi çaplarından daha küçük kapillerlerden geçebilmeleri, ancak şekil değişikliğine uğramaları ile mümkün olur (Mohandas ve diğ. 1980; Mohandas ve diğ. 1983; Mohandas 1992; Mohandas ve Chasis 1993). Eritrosit deformabilitesi intrinsik faktörlerden (sitoplazmik viskozite, membran mekanik özellikleri) ve ekstrensek faktörlerden (yüzey alanı hacim ilişkisi, hücre şekli) etkilenir (Smith ve Hochmuth 1982; Evans 1989; Numata ve diğ. 2007). Yapılan çalışmalarda, eritrositlerin içinde bulundukları ortamın ozmolaritesindeki artış (Mohandas ve Shohet 1981), ekinosit gibi şekil değişiklikleri ve sitoplazmanın reolojik özelliklerinin değişmesine neden olan orak hücre anemisindeki polimerize hemoglobin deformabilitenin azalmasına neden olur (Mohandas 1992; Clark ve diğ. 1993; Iolascon ve diğ. 1998). Bunun dışında tip II diyabet (McMillan ve diğ. 1983; Kunt ve diğ. 1999), deneysel sepsis ve iskemireperfüzyon hasarında eritrositlerin şekil değiştirme yetenekleri azalır (Kayar ve diğ. 2001).

Eritrositlerde hasar mekanizmalarının aktivasyonuna yol açan travma çeşitleri, sub-hemolitik ve hemolitik travma olmak üzere iki farklı grupta incelenir. Her iki travma çeşidinin de gelişmesinde en önemli faktör, vücut dışı dolaşım alanlarında meydana gelen fizyolojik olmayan akım koşullarıdır (Baskurt ve diğ. 2004). İnsan arteryel sistemindeki kayma kuvvetleri yaklaşık olarak 1-10 Pascal (Pa) (Greve ve diğ. 2006) arasında, vücut dışı dolaşım sistemine ait yapay sistemlerde ise 200-300 Pa veya çok daha üzerindedir (Nevaril ve diğ. 1968; Deutsch ve diğ. 2006). Sub-hemolitik travmanın sonucunda hemoliz meydana gelmez, ancak membran organizasyonunda, iyon transport sistemlerinde ve reolojik özelliklerinde değişikler meydana gelir (Dao ve diğ. 1994; Baskurt ve diğ. 2004). Yapılan çalışmalarda sub-hemolitik mekanik travmaya maruz bırakılan eritrositlerin deformabilitelerinde azalma olduğu gösterilmiştir (Kameneva ve diğ. 1995; Baskurt ve diğ. 2004). Stres uygulamasından önceki ve sonraki kan örnekleriyle yapılan ölçümlerde, uygulanan kayma kuvveti arttıkça, beklendiği gibi eritrosit deformabilitesinin de arttığı Şekil 1A'da gösterilmiştir. Stres uygulamasından önceki ve sonraki gruplara ait EI değerlerinden hesaplanan $\mathrm{SS}_{1 / 2}$ değerlerindeki değişiklikler ise Şekil 1B'de gösterilmiş ve bu değişim istatistiksel olarak anlamlı bulunmuştur $(\mathrm{p}<0.05)$.

98 I P a g e 

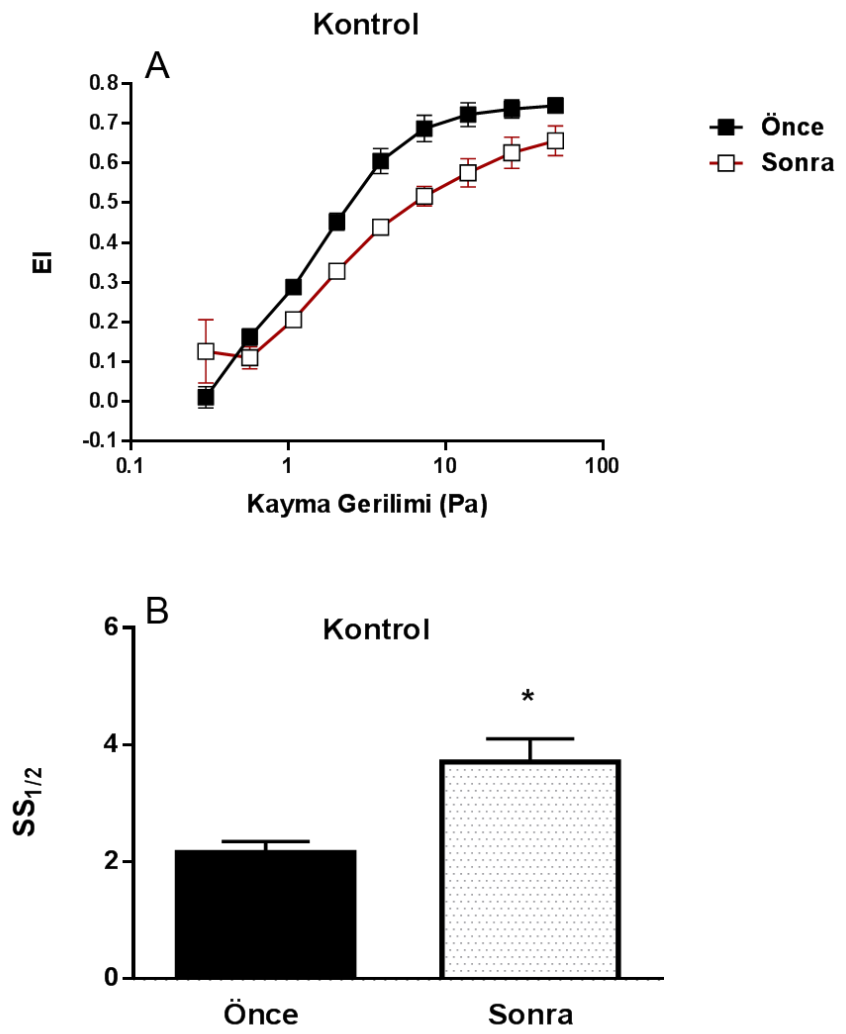

Şekil 1. A) Kontrol grubuna ait 300 saniye 290 Pa kayma hızında stres uygulamasından önceki ve sonraki kayma hızı-EI eğrisi. B) EI-kayma gerilimi eğrisinden hesaplanan maksimum elongasyon indeksinin yarısı kadar şekil değiştirmeye neden olan kayma kuvveti $\left(\mathrm{SS}_{1 / 2}\right)$. Sonuçlar ortalama \pm standart hata olarak verildi $(\mathrm{n}=10)$. “Önce'den” fark; *: $\mathrm{p}<0.05$.

Sub-hemolitik travma, eritrositlerin ömrünün kısalmasına (Brinsfield ve diğ. 1962), dalak tarafindan yakalanmasının artmasına (Sandza ve diğ. 1974), morfolojik değişikliklere (Orear ve diğ. 1984) ve mekanik özelliklerinin bozulmasına neden olabilir (Baskurt ve diğ. 2004). Başkurt ve arkadaşlarının yaptığ çalışmalarda, 290 Pa 300 saniye ektacytometry (LORRCA) ile mekanik stres uygulanan eritrositlerde hemoliz meydana gelmeden sub-hemolitik travma oluşturulduğu ve deformabilitenin azaldığı, $300 \mathrm{~Pa}$ üzerinde ise hemolizin görülmeye başlandığı gösterilmiştir (Alexy ve diğ. 2011; Baskurt 2012; Baskurt ve Meiselman 2013). Çalışmamızda da benzer sonuçlar elde edilmiştir (Şekil 1).

Final konsantrasyonu $50 \mu \mathrm{M}$ olacak şekilde Tris-NaCl tamponunda hazırlanan Seryum 10 dakika oda 1sısında inkübe edildikten sonra, stres uygulamasından önceki ve sonraki kan örnekleriyle yapılan ölçümlerde, uygulanan kayma kuvveti attıkça beklendiği gibi eritrosit deformabilitesinin de arttığı Şekil $2 \mathrm{~A}$ 'da gösterilmiştir. Stres uygulamasından önceki ve sonraki gruplara ait EI değerlerinden hesaplanan $\mathrm{SS}_{1 / 2}$ değerlerindeki değişiklikler ise Şekil 2B'de gösterilmiş ve bu değişim istatistiksel olarak anlamlı bulunmuştur $(\mathrm{p}<0.01)$. Yapılan bir çalışmada sub-hemolitik kayma geriliminin eritrosit deformabilitesinde önemli düzeyde azalmaya neden olduğu, Lanthanitler'den özellikle Lanthanum'un eritrositleri hasara karşı koruyabileceği söylenmektedir (Alexy ve diğ. 2011). Bizim çalışmamızda ise Lanthanitler'den biri olan Seryum'un eritrositleri mekanik hasara karşı korumadığı gözlenmiştir (Şekil 2). 

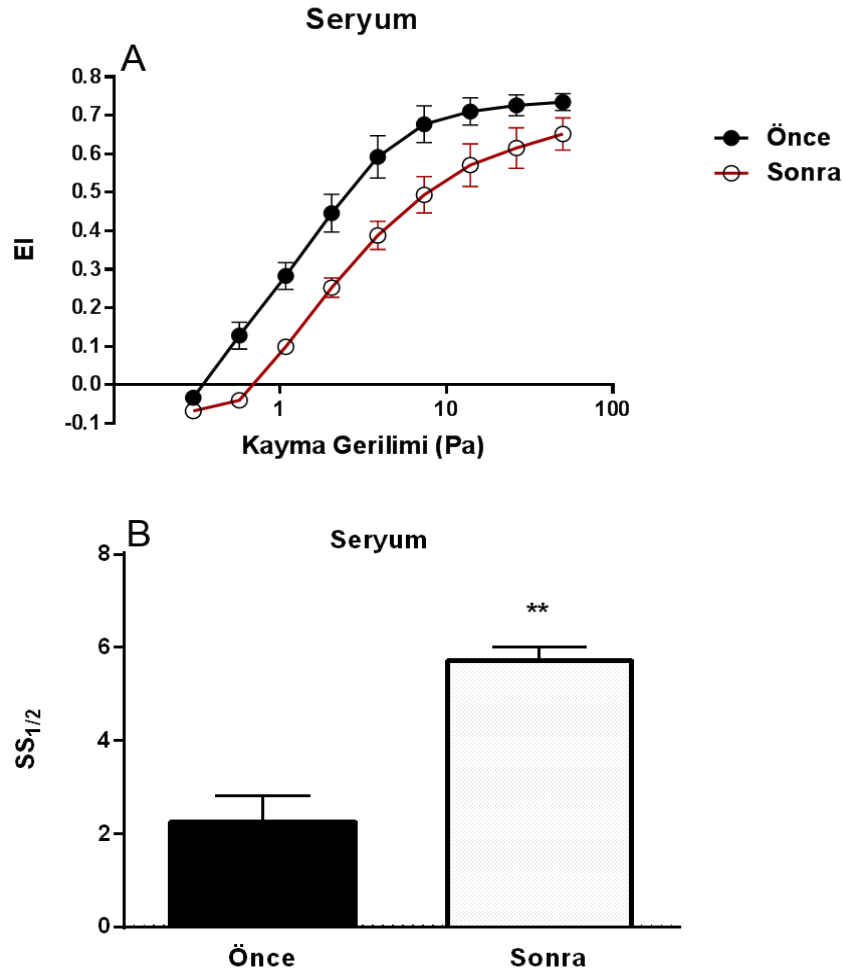

Şekil 2. A) Seryum grubuna ait 300 saniye 290 Pa kayma hızında stres uygulamasından önceki ve sonraki kayma hızı-EI eğrisi. B) EI-kayma gerilimi eğrisinden hesaplanan maksimum elongasyon indeksinin yarısı kadar şekil değiştirmeye neden olan kayma kuvveti $\left(\mathrm{SS}_{1 / 2}\right)$. Sonuçlar ortalama \pm standart hata olarak verildi $(\mathrm{n}=10)$. “Önce'den” fark; **: $\mathrm{p}<0.01$.
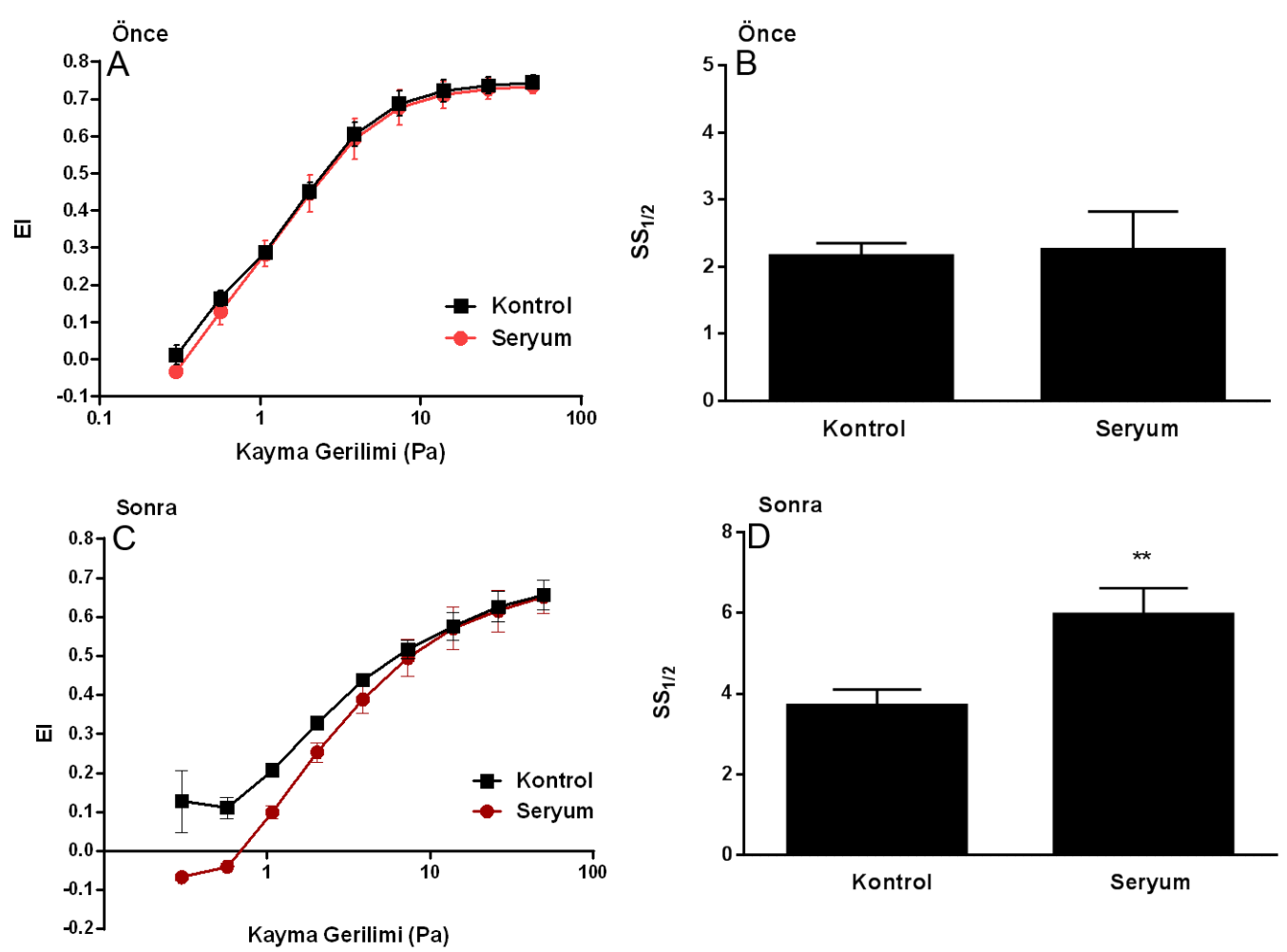

Şekil 3. A-C) Kontrol ve Seryum gruplarına ait 300 saniye 290 Pa kayma hızında stres uygulamasından önceki ve sonraki kayma hızı-EI eğrileri. B-D) Kontrol ve Seryum gruplarına ait EI-kayma gerilimi eğrisinden hesaplanan maksimum elongasyon indeksinin yarısı kadar şekil değiştirmeye neden olan kayma kuvveti $\left(\mathrm{SS}_{1 / 2}\right)$. Sonuçlar ortalama \pm standart hata olarak verildi $(\mathrm{n}=10)$. "Önce'den" fark; **: $\mathrm{p}<0.01$. 
Bu çalışmada, eritrositler kısa süreli olarak sub-hemolitik düzeyde kayma gerilimine maruz bırakılmış ve sub-hemolitik kayma geriliminin eritrosit deformabilitesine etkileri incelenmiştir. Çalışmanın bulgularına göre, eritrosit deformabilitesi mekanik stresten etkilenmekte ve sub-hemolitik kayma gerilimi, eritrosit deformabilitesinin önemli düzeyde düşmesine neden olmaktadır. Meydana gelen bu hasar, hücre zarından iyon taşınımındaki hafif bir değişiklikten, eritrositlerin tamamen yok olmasına kadar (hemoliz) değişebilir. Genel olarak, 300 Pa'dan yüksek kayma gerilmeleri hemolizle sonuçlanır (Bernhard ve diğ. 1978), düşük kayma gerilimleri ise eritrositte mekanik bozulma da dahil olmak üzere yapısal ve fonksiyonel değişikliklere neden olabilir (Giersiepen ve diğ . 1990). Yapılan çalışmalarda, kayma geriliminin insan eritrositlerinde de gerime duyarlı- $\mathrm{Ca}^{+2}$ a geçirgen katyon kanallarının açılmasını sağlayarak hücreye $\mathrm{Ca}^{+2}$ girişine neden olduğunu göstermiştir (Romero ve Romero, 1999).

Şekil 3A'da stres uygulamasından önceki Kontrol ve Seryum ile inkübe edilmiş kan örnekleriyle yapılan ölçümlerde, uygulanan kayma kuvveti attıkça her iki örneğin de eritrosit deformabilitesinin arttığ1 ve bu eğrilerden hesaplanan $\mathrm{SS}_{1 / 2}$ değerleri arasında anlamlı fark olmadığ 1 bulunmuştur (Şekil 3B). Ancak, stres uygulamasından sonraki gruplara ait EI eğrileri ve bundan hesaplanan $\mathrm{SS}_{1 / 2}$ değerlerinde önemli oranda farklar bulunmuş ve bu farkın istatistiksel olarak anlamlı olduğu belirlenmiştir (Şekil 3C-D; p<0.01). Özellikle de düşük kayma hızlarında bu fark daha ön plana çıkmıştır (Şekil 3C). Eritrositlerin Seryum ile inkübasyonu, eritrosit deformabilitesinde herhangi bir değişime neden olmazken, mekanik stres sonrası eritrositlerin deformabilitesinin daha da bozulmasına neden olmuştur. Lanthanitler'in elektron kabuklarının özelliklerinden dolayı, fiziksel ve kimyasal özellikleri birbirlerine çok benzemektedir ve bu elementler biyolojik sistemlerde kalsiyum analogları olarak işlev görürler (Martin ve Richardson 1979; Dosremedios 1981). Hücre içi artan kalsiyum konsantrasyonu eritrosit deformabilitesini düşürmektedir. Seryum'un da özellikle mekanik stres uygulamasıyla hücrenin içine girdiği ve kalsiyum gibi davranarak eritrosit deformabilitesini kontrol grubuna göre daha da düşürdüğü düşünülmektedir. Seryum'un insan fizyolojisindeki yeri tam olarak bilinmese de, çözülebilir $\mathrm{Ce}^{3+}$ tuzları (nitrat, asetat, klorür vb.) anti-emetik, bakteriyostatik, bakteri yok edici, immünomodülatör ve anti-tümör aktiviteleri için kullanılmaktadır (Ji ve diğ. 2000; Jakupec ve diğ. 2005).

Çalışmamızda da kullandığımız Seryum klorür'ün, normal şartlar altında eritrosit mekaniğine olumsuz bir etkisi olmasa da şartların değiştiği, eritrositlerin kısa süreli sub-hemolitik mekanik etkilere maruz bırakılmasıyla eritrositlerin mekanik fonksiyonlarının bozulduğu göz önünde tutulmalıdır.

\section{Kaynaklar}

Alexy T, Baskurt OK, Nemeth N, Uyuklu M, Wenby RB, Meiselman HJ. 2011. Effect of lanthanides on red blood cell deformability and response to mechanical stress: role of lanthanide ionic radius. Biorheology 48: 173-183.

Baskurt OK. 2012. Red blood cell mechanical stability. Engineering 5: 8-10.

Baskurt OK, Meiselman HJ. 2004. Analyzing shear stress-elongation index curves: comparison of two approaches to simplify data presentation. Clin Hemorheol Microcirc 31: 23-30.

Baskurt OK, Uyuklu M, Meiselman HJ. 2004. Protection of erythrocytes from sub-hemolytic mechanical damage by nitric oxide mediated inhibition of potassium leakage. Biorheology 41: 7989.

Bernhard W.F., LaFarge C.G., Liss R.H., Szycher M., Berger R.L., Poirier V. 1978. An appraisal of blood trauma and blood-prosthetic interface during left ventricular bypass in the calf and humans. Ann Thorac Surg. 26.427-37.

Brinsfield DE, Hopf MA, Geering RB, Galletti PM. 1962. Hematological changes in long-term perfusion. J Appl Physiol 17: 531-534.

Cheng Y, Huo Q, Lu J, Li R, Wang K. 1999a. The transport kinetics of lanthanide species in a single erythrocyte probed by confocal laser scanning microscopy. J Biol Inorg Chem 4: 447-456.

Cheng Y, Liu M, Li R, Wang C, Bai C, Wang K. 1999b. Gadolinium induces domain and pore formation of human erythrocyte membrane: an atomic force microscopic study. Biochim Biophys Acta 1421: 249-260. 
Cheng Y, Yao H, Lin H, Lu J, Li R, Wang K. 1999c. The events relating to lanthanide ions enhanced permeability of human erythrocyte membrane: binding, conformational change, phase transition, perforation and ion transport. Chem Biol Interact 121: 267-289.

Clark MR, Shohet SB, Gottfried EL. 1993. Hereditary hemolytic disease with increased red blood cell phosphatidylcholine and dehydration: one, two, or many disorders? Am J Hematol 42: 25-30.

Dao KM, O'Rear EA, Johnson AE, Peitersen SE. 1994. Sensitivity of the erythrocyte membrane bilayer to subhemolytic mechanical trauma as detected by fluorescence anisotropy. Biorheology 31: 69-76.

Deutsch S, Tarbell JM, Manning KB, Rosenberg G, Fontaine AA. 2006. Experimental fluid mechanics of pulsatile artificial blood pumps. Annual Review of Fluid Mechanics 38: 65-86.

Dosremedios CG. 1981. Lanthanide Ion Probes of Calcium-Binding Sites on Cellular Membranes. Cell Calcium 2: 29-51.

Evans EA. 1989. Structure and deformation properties of red blood cells: concepts and quantitative methods. Methods Enzymol 173: 3-35.

Giersiepen M., Wurzinger L.J., Opitz R., Reul H. 1990. Estimation of shear stress-related blood damage in heart valve prostheses--in vitro comparison of 25 aortic valves. Int J Artif Organs.13.300-6.

Greve JM, Les AS, Tang BT, Draney Blomme MT, Wilson NM, Dalman RL, Pelc NJ, Taylor CA. 2006. Allometric scaling of wall shear stress from mice to humans: quantification using cine phase-contrast MRI and computational fluid dynamics. Am J Physiol Heart Circ Physiol 291: H1700-1708.

Hardeman MR, Goedhart PT, Dobbe JGG, Lettinga KP. 1994. Laser-Assisted Optical Rotational Cell Analyzer (Lorca) .1. A New Instrument for Measurement of Various Structural Hemorheological Parameters. Clinical Hemorheology 14: 605-618.

Herscher CJ, Rega AF. 1996. Pre-steady-state kinetic study of the mechanism of inhibition of the plasma membrane Ca(2+)-ATPase by lanthanum. Biochemistry 35: 14917-14922.

Iolascon A, Miraglia del Giudice E, Perrotta S, Alloisio N, Morle L, Delaunay J. 1998. Hereditary spherocytosis: from clinical to molecular defects. Haematologica 83: 240-257.

Jakupec MA, Unfried P, Keppler BK. 2005. Pharmacological properties of cerium compounds. Rev Physiol Biochem Pharmacol 153: 101-111.

Ji YJ, Xiao B, Wang ZH, Cui MZ, Lu YY. 2000. The suppression effect of light rare earth elements on proliferation of two cancer cell lines. Biomed Environ Sci 13: 287-292.

Kameneva MV, Antaki JF, Borovetz HS, Griffith BP, Butler KC, Yeleswarapu KK, Watach MJ, Kormos RL. 1995. Mechanisms of red blood cell trauma in assisted circulation. Rheologic similarities of red blood cell transformations due to natural aging and mechanical stress. ASAIO J 41: M457-460.

Kayar E, Mat F, Meiselman HJ, Baskurt OK. 2001. Red blood cell rheological alterations in a rat model of ischemia-reperfusion injury. Biorheology 38: 405-414.

Kunt T, Schneider S, Pfutzner A, Goitum K, Engelbach M, Schauf B, Beyer J, Forst T. 1999. The effect of human proinsulin C-peptide on erythrocyte deformability in patients with Type I diabetes mellitus. Diabetologia 42: 465-471.

Kuypers FA. 1998. Red cell membrane damage. J Heart Valve Dis 7: 387-395.

Martin RB, Richardson FS. 1979. Lanthanides as probes for calcium in biological systems. $Q$ Rev Biophys 12: 181-209.

McMillan DE, Utterback NG, Mitchell TP. 1983. Doublet formation of diabetic erythrocytes as a model of impaired membrane viscous deformation. Microvasc Res 26: 205-220.

Mohandas N. 1992. Molecular basis for red cell membrane viscoelastic properties. Biochem Soc Trans 20: $776-782$. 
Mohandas N, Chasis JA. 1993. Red blood cell deformability, membrane material properties and shape: regulation by transmembrane, skeletal and cytosolic proteins and lipids. Semin Hematol 30: 171-192.

Mohandas N, Chasis JA, Shohet SB. 1983. The influence of membrane skeleton on red cell deformability, membrane material properties, and shape. Semin Hematol 20: 225-242.

Mohandas N, Clark MR, Jacobs MS, Shohet SB. 1980. Analysis of factors regulating erythrocyte deformability. J Clin Invest 66: 563-573.

Mohandas N, Shohet SB. 1981. The role of membrane-associated enzymes in regulation of erythrocyte shape and deformability. Clin Haematol 10: 223-237.

Nash GB, Gratzer WB. 1993. Structural determinants of the rigidity of the red cell membrane. Biorheology 30: 397-407.

Nevaril CG, Lynch EC, Alfrey CP, Jr., Hellums JD. 1968. Erythrocyte damage and destruction induced by shearing stress. J Lab Clin Med 71: 784-790.

Numata T, Shimizu T, Okada Y. 2007. TRPM7 is a stretch- and swelling-activated cation channel involved in volume regulation in human epithelial cells. Am J Physiol Cell Physiol 292: C460-467.

Orear EA, Udden MM, Farmer JA, Mcintire LV, Lynch EC. 1984. Increased Intracellular Calcium and Decreased Deformability of Erythrocytes from Prosthetic Heart-Valve Patients. Clinical Hemorheology 4: 461-471.

Romero P.J., Romero E.A. 1999. Effect of cell ageing on Ca2+ influx into human red cells. Cell Calcium.26.131-7.

Sakota D, Sakamoto R, Sobajima H, Yokoyama N, Waguri S, Ohuchi K, Takatani S. 2008. Mechanical damage of red blood cells by rotary blood pumps: selective destruction of aged red blood cells and subhemolytic trauma. Artif Organs 32: 785-791.

Sandza JG, Jr., Clark RE, Weldon CS, Sutera SP. 1974. Subhemolytic trauma of erythrocytes: recognition and sequestration by the spleen as a function of shear. Trans Am Soc Artif Intern Organs 20 B: 457-462.

Smith L, Hochmuth RM. 1982. Effect of wheat germ agglutinin on the viscoelastic properties of erythrocyte membrane. J Cell Biol 94: 7-11.

Sneddon J. 1987. Action of di- and tri-valent cations on calcium-activated K+-efflux in rat erythrocytes. Biochem Pharmacol 36: 3723-3730.

Sun HY, Lin H, Cao Y, Li R, Wang K, Chen R. 1995. Tb3+ binding to human erythrocyte spectrin resulting in conformation change and aggregation. J Inorg Biochem 59: 29-37. 